DE

M E D I C I N A

T R O P I C A L

$\mathrm{DE}$

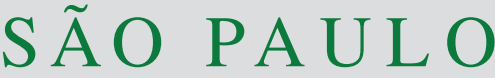

JOURNAL OF THE SÃO PAULO INSTITUTE OF TROPICAL MEDICINE

(1)Universidad de la República, Uruguay

(2)Instituto Osvaldo Cruz, Centro de Referência Nacional para Leptospirose, WHO Collaborating Center for Leptospirosis, Laboratório de Zoonoses Bacterianas, Rio de Janeiro, Rio de Janeiro, Brazil

Correspondence to: Felipe Schelotto Universidad de la República, Departamento de Bacteriología y Virología, Rua Alfredo Navarro, 3051, 11600, Montevideo, Uruguay Tel: 598 24875795, 59899166825

E-mail: felipe@ higiene.edu.uy

Received: 9 June 2017

Accepted: 12 September 2017

\section{Characterization of Leptospira isolates from humans and the environment in Uruguay}

Paulina Meny ${ }^{1}$, Clara Menéndez ${ }^{1}$, Jair Quintero', Elba Hernández ${ }^{1}$, Cristina Ríos ${ }^{1}$, llana Teruszkin Balassiano², Camilla Nunes dos Reis Trindade ${ }^{2}$, Juliana Magalhães Vital-Brazil' ${ }^{2}$, Tatiane Mendes Varela Ramos ${ }^{2}$, Natalia Ashfield', Camila Feble1, Esthefani Avila1, Felipe Schelotto', Gustavo Varela ${ }^{1}$

\section{ABSTRACT}

Laboratory diagnosis of human leptospirosis usually relies on indirect methods exploring specific immune response. Isolation and identification of the involved strains are cumbersome, but can provide biological resources for pathogenic studies and relevant information for guiding prevention and control measures. The aim of the research we are hereby reporting was the characterization of Leptospira isolates obtained from humans and the environment in Uruguay. Blood cultures were performed from early samples of 302 Uruguayan patients, mainly rural workers, and from 36 water samples taken from their living or working environments. Eight human isolates and seven environmental isolates were obtained and analyzed by end point Polymerase Chain Reaction (PCR), Multilocus Variable Number of Tandem Repeat Analysis (MLVA) and other molecular methods. Human isolates corresponded to several serogroups and serovars of Leptospira interrogans and Leptospira kirschneri species, probably reflecting the infection with similar involved Leptospira species and serovars of an extended animal reservoir in rural settings of the country, mostly dedicated to meat and dairy production. Culture-positive patients were older than usually affected workers, and presented signs and symptoms of severe illness. A high organic and circulating bacterial burden may explain an easier positive result from these workers' samples. Environmental isolates were mainly identified as Leptospira biflexa strains, with a single L. meyeri isolate of uncertain significance.

KEYWORDS: Leptospira. Human isolates. MLVA-VNTR-PCR. Leptospirosis. Environment Leptospira. Leptospira interrogans. Leptospira kirschneri. L. meyeri.

\section{INTRODUCTION}

Some estimated 500 to 1,000 human leptospiral infections occur annually in Uruguay, mainly as mild or subclinical illnesses, but sometimes with a severe course or a lethal outcome ${ }^{1}$.

Human leptospirosis presents in our country as sporadic cases or limited outbreaks occurring mainly in rainy periods or during floods, and usually affecting young males involved in cattle or dairy farming, rural work, abattoirs or animal transport. Breeding animals largely outnumber the Uruguayan population of 3.3 million people ${ }^{2}$; a variable proportion of the 6.6 million ovine and porcine livestock, and of more than 12 million bovine cattle inhabiting the country make part of the huge reservoir of this zoonosis ${ }^{3}$.

Diagnosis of leptospirosis has relied for many years on the investigation of specific antibodies through various procedures such as immunofluorescence, ELISA, 
immune-chromatographic methods for early detection of IgM and IgG, or Micro Agglutination Technique (MAT) as the reference indirect test revealing immune response to Leptospira in serum samples ${ }^{4,5}$.

MAT applied to serum samples of infected patients explores the antibody reactivity to several strains, using bacterial antigens, usually yielding positive results, but even higher titers do not reliably point out to the actual infecting species or serovar. This information can only be obtained through culture and identification of isolates.

Leptospira do not readily develop in usual microbiological media and are easily overgrown by contaminating bacteria or fungi. Nevertheless, they can be cleanly recovered from blood cultures, but only during the first days of illness. Urine cultures can possibly be performed for some further weeks because bacteria are eliminated in this fluid for longer periods; nevertheless, isolation from this source is not easy due to difficulties for obtaining and transporting samples without contamination, and because of the short survival of Leptospira in acid urine samples.

Anyway, isolation of Leptospira from human infections, although cumbersome and difficult ${ }^{6}$, must be attempted for epidemiological reasons, aiming to identifying involved species and serovars, comparing isolates with those obtained from animal reservoir to study infection sources and routes, and to select important strains for animal and human vaccine development.

PCR assays, and qPCR, since 2000, have also been applied as useful diagnostic tools, but their performance is satisfactory on blood samples only during the initial days of illness, when blood cultures are potentially positive ${ }^{7-9}$.

Molecular identification methods such as Multilocus Variable number tandem-repeat Analysis, (MLVA), Multilocus Sequence typing (MLST), Pulsed-Field Gel Electrophoresis (PFGE), and partial or whole-genome sequencing (P-WGS) are increasingly employed for further characterization of isolates. When combined with serotyping, they enable to define species, serovars and strain variants, providing information of great value for epidemiological, pathogenic and preventive studies of Leptospira infections ${ }^{10,11}$.

No previous work has been carried out in our country regarding the characterization of human and environmental Leptospira isolates. As part of our program of individual diagnosis and epidemiological study of leptospirosis in Uruguay, we decided to regularly perform blood cultures from presumptively infected persons that are routinely examined by MAT. Urine, organs or blood cultures from animal reservoir, and environmental cultures from water collections or resources in sites where human or animal infections have been reported were also included.
The aim of the research that we are hereby reporting was the recovery and molecular identification of isolates from human and environmental origin, as performed in our laboratories (Bacteriology and Virology Department, Hygiene Institute, Universidad de la República, Uruguay) with co-workers from the Instituto Oswaldo Cruz, Rio de Janeiro, Brazil.

\section{MATERIAL AND METHODS}

\section{Sample collection and culture conditions}

This study was performed from January 2010 to December 2016. In this period, serum antibodies from 4,200 patients and blood cultures from 302 of them were studied. Samples were obtained and sent by Health workers for diagnosis of human patients with suspected leptospirosis, mainly living in rural areas. Thirty six samples were additionaly obtained and cultured by our workgroup from urban water collections close to human slum houses, or from water collections found in cattle raising and dairy farms where positive human cases had been confirmed, and which harboured at risk population groups holding extended contact with the animal reservoir.

Blood cultures were seeded from blood collected in EDTA tubes which were usually accompanied by the first serum sample of the same patient and by a record form providing relevant clinical and epidemiological information (personal data, onset date of symptoms and of blood extraction, type of patient's work and others).

When blood had been extracted no more than ten days after the illness onset, it was inoculated into two culture media: Ellinghausen-McCullough-Johnson-Harris EMJH broth $\left(\right.$ Difco-BD ${ }^{\circledR}$ ) and Fletcher semisolid medium (Difco-BD ${ }^{\circledR}$ ) supplemented with membrane-filtered inactivated rabbit serum. Two drops (50-100 uL) of blood were included into five $\mathrm{mL}$ of media prepared in screw-capped tubes.

Water samples were collected in sterile plastic containers, slowly filtered through 0.22 -uM pore membranes and inoculated $(0.5 \mathrm{~mL})$ into the same both media and tubes.

Culture tubes were placed in $28{ }^{\circ} \mathrm{C}$ incubators, and examined periodically under dark field microscopy, with 600x (40x15) magnification, in a Nikon Eclipse Ci-L ${ }^{\circledR}$ equipment. The first observation was performed one or two weeks after inoculation, and then weekly until six to eight months' incubation ${ }^{5,12}$.

Visually suspected positive cultures were subcultured in the above-mentioned media, and if a mixed flora was found or presumed, membrane filtration or inoculation into EMJH with $200 \mu \mathrm{g} / \mathrm{mL}$ 5-Fluorouracil (or both) were performed for selecting Leptospira. 


\section{Bacterial DNA extraction for PCR assays}

DNA of suggestive cultures with turbidity equivalent to 0.5 in the McFarland scale $\left(1.5 \times 10^{8}\right.$ bacteria/mL $)$ was extracted through silica gel column with DNeasy Blood \& Tissue $^{\circledR}$ kit (Qiagen ${ }^{\circledast}$, Germany), following the manufacturer instructions. The DNA was kept frozen at $-20^{\circ} \mathrm{C}$ until use.

\section{PCR (Polymerase Chain Reaction)}

The extracted nucleic acid was analyzed by end point PCR.LipL32-45F and LipL32-286R primers were used to amplify gene sequences coding for the LipL32 membrane lipoprotein which is only found in pathogenic Leptospira $^{13}$. To amplify Leptospira $16 \mathrm{~S}$ ribosomal RNA coding sequences, primers were LeptoA $F$ and LeptoB $\mathrm{R}^{14}$. Saprophytic Leptospira can yield positive $16 \mathrm{~S}$ results, but not LipL32 amplicons ${ }^{15}$.

Both amplifications were performed in a total volume of $25 \mathrm{uL}$, including $1 \mathrm{X}$ Buffer (10 mM Tris- $\mathrm{HCl}$, $\mathrm{pH} 8.8$, $50 \mathrm{mM} \mathrm{KCl}$ ), $2.5 \mathrm{mM} \mathrm{MgCl}, 0.2 \mathrm{mM}$ dNTPs, $0.64 \mathrm{uM}$ of each LipL32 primer (SBS Genetech Co. Ltd.) and $0.5 \mathrm{uM}$ for $16 \mathrm{~S}$ primers, $1 \mathrm{ug} / \mathrm{uL}$ BSA (Bovine Serum Albumin, fraction V, Sigma ${ }^{\circledR}$ ), 1.5U DNA Taq polymerase (Thermofisher Scientific inc. $\left.{ }^{\circledR}\right)$ and 1 uL DNA template.

Conditions were the same for both reactions, consisting of an initial denaturation step of $5 \mathrm{~min}$ at $95^{\circ} \mathrm{C}$ followed by 35 cycles of $30 \mathrm{~s}$ at $95^{\circ} \mathrm{C}, 30 \mathrm{~s}$ at $57^{\circ} \mathrm{C}$, and $30 \mathrm{~s}$ at $72^{\circ} \mathrm{C}$. The final extension step was set at $72^{\circ} \mathrm{C}$ for $10 \mathrm{~min}$.

Amplification reactions were carried out in a Gene Amp PCR System 2700 thermocycler (Applied Biosystems ${ }^{\circledR}$, California, USA).

PCR products were loaded in $2 \%$ agarose gels prepared in 0.5X Tris-Borate-EDTA (TBE) buffer and separated by electrophoresis at $100 \mathrm{~V}$ for $45 \mathrm{~min}$. DNA bands were revealed by ethidium bromide staining and visualized with UV light in the FOTO/Analyst Investigator Eclipse FOTODYNE $^{\circledR}$ system (Thermo Fisher Scientific, Waltham, MA, USA).

An additional $\mathrm{PCR}$ primer pair, $23 S$-P1 and $23 S-\mathrm{P} 2^{16}$, was applied to water isolates yielding positive $16 \mathrm{~S}$ and negative LipL32 results for differentiating L. biflexa isolates from those of other saprophytic Leptospira species. In amplifications, $0.8 \mathrm{uM}$ of $23 \mathrm{~S}-\mathrm{P} 1$ and $23 S$-P2 primers were used with the same reaction conditions as those of $16 \mathrm{SPCR}$, except for the annealing temperature, which was set at $54{ }^{\circ} \mathrm{C}$.

\section{MLVA (Multilocus Variable-Number of Tandem Repeat} (VNTR) Analysis)

Human isolates showing positive $16 S$ and LipL32 PCR results were kept in Fletcher or EMJH semisolid media, subcultured bimonthly and later studied through the MLVA molecular typing procedure, seeking for individual VNTR profiles that may contribute to a more precise identification of strains in terms of species and serovar. Three primer pairs were used to amplify VNTR 4, VNTR 7 and VNTR 10 loci according to methods published by Salaün et al. ${ }^{17}$. They allow characterizing strains of $L$. interrogans, L. borgpetersenii and L. kirschneri.

PCR reactions were carried out in a total volume of $25 \mathrm{uL}$, with 1X Buffer (10 mM Tris-HCl, $\mathrm{pH} 8.8,50 \mathrm{mM}$ $\mathrm{KCl}), 1.4 \mathrm{mM} \mathrm{MgCl}, 0.2 \mathrm{mM}$ dNTPs, $0.4 \mathrm{uM}$ primers, $1.3 \mathrm{U}$ Taq DNA polymerase (Thermofisher ${ }^{\circledR}$ ) and $2.5 \mathrm{uL}$ of template DNA. The amplification program included an initial 5 min denaturation step at $94{ }^{\circ} \mathrm{C}$, followed by 35 cycles of $30 \mathrm{~s}$ at $94{ }^{\circ} \mathrm{C}, 30 \mathrm{~s}$ at $55^{\circ} \mathrm{C}$, and $1 \mathrm{~min} 30 \mathrm{~s}$ at $72{ }^{\circ} \mathrm{C}$. The final extension step was set at $72{ }^{\circ} \mathrm{C}$ for 10 min. Agarose gel electrophoresis and examination of DNA bands were performed as described above.

\section{PFGE (Pulsed-Field Gel Electrophoresis)}

Two of the six available isolates, obtained from patients with negative MAT results, were selected for MLST and PFGE analysis.

PFGE was performed following a modified technique published by Galloway and Levett ${ }^{11}$. Bacterial suspensions were adjusted to an optical density of 1.4 at $610 \mathrm{~nm}$, mixed with equal volume of $1.2 \%$ pulse-field grade certified agarose solution preheated to $55^{\circ} \mathrm{C}$ (Bio-Rad, Hercules, CA, USA), and placed into suitable molds. Plugs were washed six times with wash solution, cut into ca. $2 \mathrm{~mm}$ height pieces and digested for $2 \mathrm{~h}$ at $37^{\circ} \mathrm{C}$ with $25 \mathrm{U}$ of Not I restriction enzyme (New England Biolabs Inc., Ipswich, MA, USA).

Separation of DNA fragments was performed using a CHEF DR-II system (Bio-Rad). Salmonella enterica serotype Braenderup (CDCH9812) was used as a DNA standard pattern ${ }^{18}$.

Gels were stained with ethidium bromide, washed three times with distilled water, and examined by an image capture system, as mentioned.

\section{MLST (Multilocus Sequence Typing)}

MLST was performed on both human isolates that were also examined through PFGE. According to the procedure previously described by Boonsilp et al. ${ }^{19}$, amplification of internal sequences from seven house-keeping genes $(g \operatorname{lm} U$, pntA, pfkB, caiB, mreA, sucA and tpiA) was followed by sequencing of the obtained DNA products. Five uL of 
each endpoint PCR product were run in $2 \%$ agarose gel electrophoresis to determine if the amplification had been effective. The remaining volume was sequenced in RPT01A-PDTIS/FIOCRUZ DNA sequencing equipment (http://plataformas.cdts.fiocruz.br/). Sequences were then entered into the database (http://leptospira.mlst.net/; https://pubmlst.org/leptospira/) and matched with known allelic sequences using the MAFFT program for multiple sequences alignment (www.ebi.ac.uk/Tools $/ \mathrm{msa} / \mathrm{mafft} /)^{20}$ to determine the allelic profile and Sequence Type (ST) of the examined strains.

\section{Partial 165 rDNA sequencing}

Lepto A and Lepto B primers ${ }^{14}$ were used to amplify a 330 bp size segment from the $16 \mathrm{~S}$ rDNA gene of each strain. Amplicon sequencing was performed in both directions at the IPMont (Institut Pasteur, Montevideo) using primers LeptoC 5' CAAGTCAAGCGGAGTAGCA-3' and S45' TCTTAACTGCTGCCTCCCGT-3'. The obtained sequences were compared with those of strains deposited on GenBank using the BLAST tool (https://blast.ncbi.nlm. nih.gov/Blast.cgi). Results are shown in Table 1.
Micro-Agglutination Technique for serum antibodies investigation

MAT was performed in all serum samples according to the standard technique with a two-step procedure ${ }^{1,4,21}$. Each serum was initially diluted 1:25 in saline and mixed with equal volumes of each of the 20 live cultures of Leptospira serovars that yield reactive results very frequently in the region and are able to promote cross-reactions. The serogroups and serovars of the employed strains were: Australis Australis; Australis Bratislava; Autumnalis Autumnalis; Autumnalis Butembo; Ballum Castellonis; Bataviae Bataviae; Canicola Canicola; Cynopteri Cynopteri; Grippotyphosa Gryppotyphosa; Hebdomadis Hebdomadis; Icterohaemorrhagiae Copenhageni; Mini Mini; Pomona Pomona; Pomona Kennewicki; Pyrogenes Pyrogenes; Sejroe Hardjo; Sejroe Sejroe; Sejroe Wolffii; Semaranga Patoc; Tarassovi Tarassovi.

In a second step, agglutinating serovars were tested against serial dilutions of the patient's serum. Titers equal or higher than 400 in a single serum sample against at least one serovar were considered a confirmed case of leptospirosis. In addition, a fourfold increase in titers from the acute to the convalescent sample was interpreted as a confirmed result.

Table 1 - Identification of human and environment isolates

\begin{tabular}{|c|c|c|c|c|c|c|c|c|c|}
\hline & $\begin{array}{l}\text { ISOLATE } \\
\text { ID }\end{array}$ & $\begin{array}{c}\text { MAT } \\
\text { RESULT }\end{array}$ & $\begin{array}{l}\text { PCR LipL32/ } \\
\text { 16SrRNA }^{12,13}\end{array}$ & $\begin{array}{l}23 S \\
\text { PCR }^{15}\end{array}$ & $\begin{array}{c}\text { MLVA }^{16} \\
\text { ANALYSIS }\end{array}$ & $\begin{array}{l}\text { PFGE }{ }^{11} \\
\text { ANALYSIS }\end{array}$ & $\mathrm{MLST}^{18}$ & Sequencing* & Identification \\
\hline \multirow{6}{*}{ 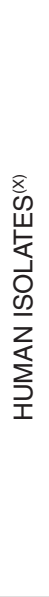 } & $\mathrm{AH} 1$ & $\begin{array}{l}1^{\text {st }} \text { pos } \\
2^{\text {nd }} \text { pos }\end{array}$ & pos/pos & ND & ND & ND & ND & L. interrogans & $\begin{array}{c}\text { L. interrogans Pomona } \\
\text { Pomona }\end{array}$ \\
\hline & $\begin{array}{c}\mathrm{AH} 2 \\
\left(2^{\mathrm{x}}\right)\end{array}$ & $\begin{array}{l}\text { only one neg } \\
\text { sample }\end{array}$ & pos/pos & ND & $5-0-10$ & $\begin{array}{c}\text { L.interrogans } \\
\text { Pomona } \\
\text { Kennewicki }\end{array}$ & ST 140 & L. interrogans & $\begin{array}{l}\text { L. interrogans Pomona } \\
\text { Kennewicki }\end{array}$ \\
\hline & $\begin{array}{l}\mathrm{AH} 3 \\
\left(3^{x}\right)\end{array}$ & $\begin{array}{l}\text { only one neg } \\
\text { sample }\end{array}$ & pos/pos & ND & $1-10-3$ & $\begin{array}{c}\text { L.interrogans } \\
\text { Canicola } \\
\text { Canicola/ } \\
\text { Portlandvere }\end{array}$ & ST 37 & L. interrogans & $\begin{array}{l}\text { L. interrogans Canicola } \\
\text { Canic/Portlandvere }\end{array}$ \\
\hline & $\begin{array}{c}\mathrm{AH} 4 \\
\left(6^{\times}\right)\end{array}$ & $\begin{array}{l}1^{\text {st }} \text { neg } \\
2^{\text {nd }} \text { pos }\end{array}$ & pos/pos & ND & $3-2-11$ & ND & ND & L. interrogans & $\begin{array}{l}\text { L. interrogans Sejroe } \\
\text { Wolffi/Romanica }\end{array}$ \\
\hline & $\begin{array}{l}\text { AH5 } \\
\left(10^{x}\right)\end{array}$ & $\begin{array}{l}\text { only one pos } \\
\text { sample }\end{array}$ & pos/pos & ND & $1-5-4$ & ND & ND & L. kirschneri & $\begin{array}{c}\text { L. kirschneri Australis } \\
\text { Ramisi }\end{array}$ \\
\hline & $\begin{array}{l}\mathrm{AH} 6 \\
\left(4^{\mathrm{x}}\right)\end{array}$ & $\begin{array}{l}1^{\text {st }} \text { neg } \\
2^{\text {nd }} \text { pos }\end{array}$ & pos/pos & ND & ND & ND & ND & L. kirschneri & $\begin{array}{l}\text { L. kirschneri serov. } \\
\text { Mozdok? }\end{array}$ \\
\hline \multirow{7}{*}{ 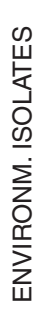 } & $\mathrm{AA} 1^{\#}$ & ND* & neg/pos & neg & ND & ND & ND & L. meyeri & Leptospira meyeri \\
\hline & $\mathrm{AA} 2^{\#}$ & ND & neg/pos & pos & ND & ND & ND & ND & Leptospira biflexa \\
\hline & $\mathrm{AA}^{\# \#}$ & ND & neg/pos & pos & ND & ND & ND & ND & Leptospira biflexa \\
\hline & $\mathrm{AA} 4^{\# \#}$ & ND & neg/pos & pos & ND & ND & ND & ND & Leptospira biflexa \\
\hline & AA5"\# & ND & neg/pos & pos & ND & ND & ND & ND & Leptospira biflexa \\
\hline & AA6"\# & ND & neg/pos & pos & ND & ND & ND & ND & Leptospira biflexa \\
\hline & $\mathrm{AA} 7^{+}$ & ND & neg/pos & pos & ND & ND & ND & ND & Leptospira biflexa \\
\hline
\end{tabular}

*: Partial $16 S$ sequence; **: not done; ${ }^{\mathrm{x}}$ : time (days) elapsed between onset of symptoms and blood extraction for culture; \#: water from slums; \#\#: water from rural cattle or dairy farms; +: water from a small island. 


\section{RESULTS}

\section{Human isolates}

Eight blood cultures were identified as positive in the considered period through a presumptive microscopic observation and molecular confirmation methods. They were positive through both $16 S$ and LipL32 PCR, indicating they are pathogenic isolates, as expected of bacteria recovered from symptomatic patients with signs compatible with leptospirosis.

Positive blood cultures were usually detected in both inoculated media (Fletcher and EMJH), although estimated initial bacterial populations (through dark field microscopy) were not equal. AH4 was only recovered from EMJH, and AH6 solely from Fletcher. All positive cultures were obtained from rural workers, most of them laboring in dairy farms, located in Southern departments of the country. Their age varied from 32 to 63 years old, and evolution of illness was frequently severe, with liver involvement or other organic disorders, added to general signs and symptoms of fever, headache, asthenia, myalgia and arthralgia. MAT tests were negative in three cases, because no second sample was obtained to study seroconversion. When MAT was positive in the first or second serum sample, the isolated serovar did not correspond to the serovar of the reference strain yielding the highest antibody titer.

Six isolates could be further characterized. The first one, AH1, was identified by serotyping as Leptospira interrogans serogroup Pomona, serovar Pomona in Leptospirosis Reference Laboratory of Queensland, Australia. Four additional human isolates could be studied through MLVA with primers to amplify VNTR 4, 7 and 10 . The number of copies of the corresponding VNTR fragments, as shown in Table 1, could be calculated from the amplicon molecular weights leading to advanced identification when comparing problem strain profiles with those published from reference strains. A sixth recent isolate, AH6, is still being examined.

Partial sequencing of $16 \mathrm{~S}$ rDNA afforded solid data identifying species (Table 1), but did not allow to assert clear serovar results for all strains. However, combining those data with obtained VNTR profiles by the MLVA technique, and based on reference data published by Salaün et al. ${ }^{17}$, we can state that the $\mathrm{AH} 2$ isolate belongs to Leptospira interrogans species, serogroup Pomona, serovar Kennewicki (Figure 1); the AH3 isolate to Leptospira interrogans serogroup Canicola serovar Canicola or serovar Portlandvere; the AH4 isolate to Leptospira interrogans serogroup Sejroe, serovar Wolffii or serovar Romanica, and the AH5 isolate to Leptospira kirschneri serogroup Australis, serovar Ramisi.

For AH3 and AH4 cultures, it was not possible to differentiate between 2 serovars with the employed primers and the target VNTRs.

The BLAST analysis of sequences amplified from the AH6 isolate showed 100\% identity of $16 \mathrm{~S}$ rRNA with L. kirschneri serovar Mozdok (GenBank access $\mathrm{N}^{\circ} \mathrm{KP}$ 125531.1).

PFGE was applied to AH2 and AH3 strains. Clearcut results were obtained with the $\mathrm{AH} 2$ isolate: its PFGE pattern only matched with that of the reference strain $L$. interrogans serogroup Pomona, serovar Kennewicki. Conversely, the AH3 pattern matched both Canicola and Portlandvere serovars of $L$. interrogans serogroup Canicola (Figure 2), hindering further differentiation.

$\mathrm{AH} 2$ and $\mathrm{AH} 3$ were also studied by using MLST assays. PCR image revealed that in both cases amplification was positive for all seven gene fragments, enabling further sequencing. The analysis of amplicon sequences from all seven genes revealed that the $\mathrm{AH} 2$ isolate could be assigned to ST 140 and AH3 to ST 37 (Table 1).

In PUBMLST Leptospira database, serogroup Pomona

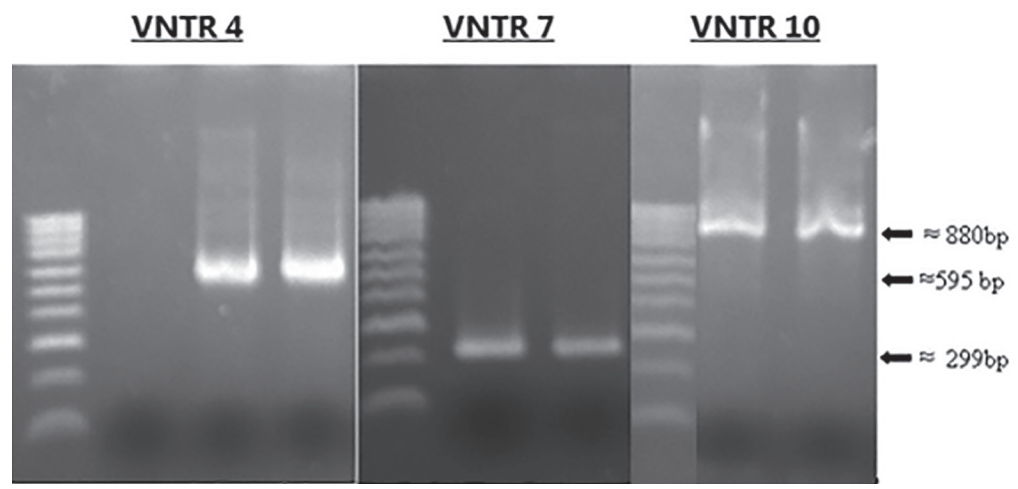

Figure 1 - Results obtained by VNTR assays with the AH2 human isolate corresponding to Leptospira interrogans Pomona Kennewicki. VNTR 4: lane 1, DNA ladder 100 bp (Bioline, Meridian®; lane 2, negative control; lane 3, isolate \#AH2; lane 4, strain IH23 L. interrogans Pomona Kennewicki. VTR7: lane 1, DNA ladder 100 bp; lane 2, isolate \#AH2; lane 3, strain L. interrogans Pomona Kennewicki. VNTR 10: lane 1, DNA ladder 100 bp; lane 2, isolate \#AH2; lane 3, strain L. interrogans Pomona Kennewicki. 


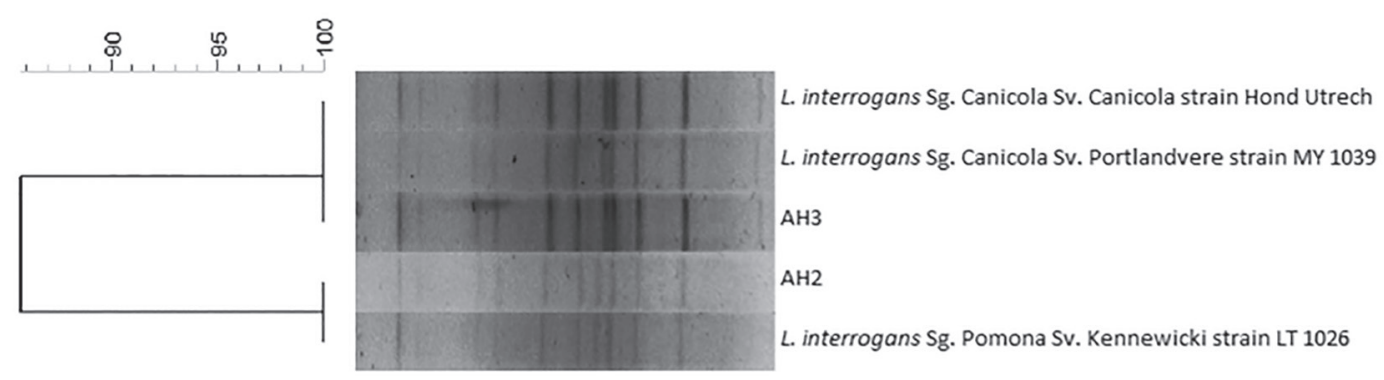

Figure 2 - PFGE image and dendrogram showing that the AH2 pattern matches that of the reference strain L. interrogans Pomona Kennewicki (P.K) and the $\mathrm{AH} 3$ pattern corresponds to those of L. interrogans Canicola Canicola (C.C) and Canicola Portlandvere (C.P). Dice (Opt: $1.50 \%)$ (Tol 1.5\%) (H>0.0\% S>0.0\%) [0.0\%-100.0\%] Notl

serovar Pomona and serovars Grippothyphosa and Pyrogenes are included in the same 140 ST. Similarly, serogroup Canicola serovar Canicola, and serogroup Pyrogenes serovar Pyrogenes share the same ST 37 sequence type.

\section{Environmental isolates}

Seven environmental positive cultures have also been recovered. Two of them (AA1 and AA2) were isolated from water collections sampled in slums surrounding Montevideo, one (AA7) from a water supply well of a small island, and four (AA3-AA6) from rural cattle or dairy farms where human leptospirosis cases had been identified.

Five of seven isolates were identified as Leptospira biflexa according to $16 S$ and $23 S$ PCR results. A sixth isolate yielded a positive $16 \mathrm{~S}$ PCR, but sequencing revealed it belongs to the Leptonema illini species. AA1 yielded negative results in both $23 S$ and LipL32 PCR, and positive $16 S$ reaction, indicating it was a saprophytic or partially pathogenic Leptospira of a different species. Sequencing of amplified $16 \mathrm{~S}$ fragment enabled to conclude that it is a Leptospira meyeri isolate.

\section{DISCUSSION}

Leptospira isolation has only recently been included in diagnostic and epidemiologic studies about leptospirosis in Uruguay, after an extended period in which knowledge was only based on clinical approach and indirect laboratory methods. This paper reports the first results obtained in our country with culture and identification procedures, which require prolonged and careful work to build a solid contribution to the control of this important zoonosis.

Blood culture performance data from either the Fletcher or EMJH media confirm that benefits are obtained by employing both culture media. Positive cultures of these bacteria must be thoroughly purified and periodically subcultured, or preserved by freezing to keep viable bacterial populations, enabling their full identification.
Isolates can otherwise be lost due to contaminants that overgrow Leptospira or to progressive irreversible cell damage. Thus, six of our eight initially recovered isolates could be successfully maintained, and five of them have already been extensively identified.

In the considered period, the number of inoculated blood cultures was slightly higher than 300, selecting samples usually taken no further than 10 days after the onset of illness. Eight positive results represent little more than $2 \%$ of the analyzed samples (CI 95\% [0.8-4.4]). This proportion is not satisfactory and can probably be improved with frequent, careful microscopic observation and subcultures ${ }^{22-24}$.

In future studies, a more strict selection of early blood samples for culture may improve the rate of positive results though reducing the total number of obtained isolates required for broadening the bacterial identification scope.

Most patients yielding positive cultures were older than those composing the general group of leptospirosis cases diagnosed through MAT (usually 20-40 years old in a previous study) ${ }^{1}$. Their illness appeared to be particularly severe, showing jaundice and organ dysfunction and requiring prolonged hospitalization. We had described in a 10-year follow-up that patients aged 40 years old or more developed jaundice more frequently than younger workers ${ }^{1}$. A high organic and circulating bacterial burden may explain an easier positive result from severely affected patients.

In many patients, a convalescent-phase serum sample is not collected for several reasons (uninformed health personnel, communication difficulties, illness improvement that leads to the belief that repeated studies are unnecessary). In this series, three patients with initial negative MAT result and without second MAT assays showed positive blood cultures, stressing the need for a complete diagnosis of leptospirosis. Positive culture results are usually delayed and not useful for guiding the patient care, but anyway may contribute to the epidemiological knowledge.

When MAT positive results were available together with positive blood cultures, differences were observed between 
isolated serovar and serovar yielding maximum serum titer, reminding us that cross-reactions are frequent and MAT results should not be taken as a source of information about the infecting serovar in humans or animals ${ }^{25}$.

Twenty known Leptospira species have been differentiated through DNA sequencing studies 5 . Nine of these are human or animal pathogenic species: $L$. interrogans, L. borgpetersenii, L. kirschneri, L. santarosai, L. kmetyi, L. weilii, L. alexanderi, L. alstoni and L. noguchii. There is a defined set of saprophytic species of different evolutionary history; an additional group of partially pathogenic species can be found both in environmental and clinical settings, and they require more studies to understand their role in infection ${ }^{26,27}$.

Human isolates were diverse in our series, corresponding to known pathogenic species (four $L$. interrogans isolates, two L. kirschneri) and included two different variants of Leptospira interrogans, Pomona serogroup. In two additional cases, it was not possible to maintain viable cultures to determine the bacterial species or to complete its molecular study. A recently confirmed isolate is still being examined.

Serovar definition of three studied isolates requires further analysis, especially for the AH5 isolate, whose VNTR profile does not enable fully solid conclusions.

Combination of several molecular techniques has proven to be useful for identifying isolates, and serologic studies could allow completing the characterization of pending cases, though requiring expensive and hardly available resources.

Identification of human infecting Leptospira has not been frequently published in reports from neighboring countries. In urban settings, L. interrogans serovar Icterohaemorrhagiae has been usually identified in Brazil ${ }^{28}$. Other species and serovars are probably common in rural and other areas, including $L$. noguchii ${ }^{29}$. and $L$. kirschneri ${ }^{30}$. L. santarosai has been reported in Northwestern Colombia and nearby countries ${ }^{31}$. Leptospira isolates reported from Argentina have been generally obtained from animals; Pomona serogroup is prevalent in bovine cattle population ${ }^{32}$. Leptospira interrogans serogroups Canicola, Sejroe, Icterohaemorrhagiae and others have been isolated from humans ${ }^{33}$.

Given the suggestive epidemiologic data, identified Uruguayan human cultures probably reflect infection of animal reservoir in rural settings with similar involvement of Leptospira species and serovars. Serovar Icterohaemorrhagiae, a common isolate from urban samples in the region, has not been identified in our small series. It is usually considered the origin of severe human cases, which in this study were found to be caused by other serovars. A collaborative project is presently ongoing for isolating, identifying and comparing bovine isolates with human infecting variants. These data will be important for guiding vaccine development and prevention of animal and human illness considering health and economic reasons.

Rural workers in contact with bovine cattle, especially in dairy farms, are the most frequently infected persons in our country, and such is the case of the patients with positive blood cultures. Prevention measures are strongly required for these human groups at risk, through personal protection equipment (gloves, boots), education and cattle immunization. Saprophytic, intermediate or pathogenic species of Leptospira can all survive for extended periods in aquatic environments with poor nutrient content ${ }^{34}$. Water isolates examined in this study were taken from environments where humans and animals of diverse species (bovine cattle, synanthropic and wild rodents, otters, horses, dogs) are potential hosts of pathogenic strains which could thus, be expected to be found in cultures. Among other studies, a Chilean report has recently confirmed this chance ${ }^{35,36}$. However, nearly all identified species in our series were saprophytic, mainly of Leptospira biflexa species, as defined with primers $23 S$-P1 and $23 S-\mathrm{P} 2$, that allow to amplify specific $23 S$ rRNA coding sequences from L. biflexa, differentiating this species from other saprophytic Leptospira. There was a single exception: one L. meyeri isolate, which is difficult to be taxonomically classified because this species includes pathogenic serovars, such as Sophia, and saprophytic serovars such as Semaranga; other L. meyeri serovars, e.g. Perameles and Ranarum, can be found in both pathogenic and saprophytic subgroups ${ }^{31}$. The presence of this species in environmental water sources may be important, due to its potential pathogenicity, and requires further characterization through serovar specific antisera or other procedures.

Following this brief report, Leptospira isolation and identification in Uruguay from human, animal and environmental sources must be increasingly performed and technically improved through scientific cooperation, for obtaining a reliable picture of bacterial variants' distribution and spread that may guide valuable preventive actions.

\section{ACKNOWLEDGEMENTS}

Thanks to Dr. María Hortal and Dr. Raquel Demarco for technical and language revision, respectively.

\section{REFERENCES}

1. Schelotto F, Hernández E, González S, Del Monte A, Ifrán S, Flores K, et al. A ten year follow up of human leptospirosis in Uruguay: an unresolved health problem. Rev Inst Med Trop Sao Paulo. 2012;54:69-75. 
2. Uruguay. Instituto Nacional de Estadística. Uruguay en cifras 2013. [cited 2017 Sept 12]. Available from: http://www.ine. gub.uy/documents/10181/39317/Uruguay+en+cifras+2013. pdf/5d3469e9-3c7f-4f6a-9f81-d7ce83f87a65

3. Uruguay. Ministerio de Ganadería, Agricultura y Pesca. Anuario estadístico de DIEA 2016. [cited 2017 Sep 12]. Available from: http://www.mgap.gub.uy/unidad-ejecutora/oficinade-programacion-y-politicas-agropecuarias/publicaciones/ anuarios-diea/anuario2016

4. Reller ME, Wunder EA Jr, Miles JJ, Flom JE, Mayorga O, Woods $\mathrm{CW}$, et al. Unsuspected leptospirosis is a cause of acute febrile illness in Nicaragua. PLoS Negl Trop Dis. 2014;8:e2941.

5. Adler B, editor. Leptospira and leptospirosis. Heidelberg: Springer; 2015. (Current topics in microbiology and immunology; v.387)

6. Boonsilp S, Thaipadungpanit J, Amornchai P, Wuthiekanun V, Chierakul W, Limmathurotsakul D, et al. Molecular detection and speciation of pathogenic Leptospira spp. in blood from patients with culture-negative leptospirosis. BMC Infect Dis. 2011;11:338.

7. González S, Geymonat JP, Hernández E, Marqués JM, Schelotto F, Varela G. Usefulness of real-time PCR assay targeting lipL32 gene for diagnosis of human leptospirosis in Uruguay. J Infect Dev Ctries. 2013;7:941-5.

8. Mullan S, Panwala TH. Polymerase chain reaction: an important tool for early diagnosis of leptospirosis cases. J Clin Diagn Res. 2016;10:DC08-11.

9. García-Ruíz D, Martínez-Guzmán MA, Cárdenas-Vargas A, Marino-Marmolejo E, Gutiérrez-Ortega A, González-Díaz E, et al. Detection of dengue, west Nile virus, rickettsiosis and leptospirosis by a new real-time PCR strategy. Springerplus. 2016;5:671.

10. Ahmed N, Devi M, Valverde MA, Vijayachari P, Machang'u RS, Ellis WA, et al. Multilocus sequence typing method for identification and genotypic classification of pathogenic Leptospira species. Ann Clin Microbiol Antimicrob. 2006;5:28.

11. Galloway RL, Levett PN. Application and validation of PFGE for serovar identification of Leptospira clinical isolates. PLoS Negl Trop Dis. 2010;4:e824.

12. Rosetti C, Cacchione R, Farace MI, Mazzonelli D, Brihuega B. Curso teórico-práctico de introducción al diagnóstico de la leptospirosis animal. Buenos Aires: Instituto Nacional de Tecnología Agropecuaria; 1999.

13. Stoddard RA, Gee JE, Wilkins PP, McCaustland K, Hoffmaster AR. Detection of pathogenic Leptospira spp. through TaqMan polymerase chain reaction targeting the LipL32 gene. Diagn Microbiol Infect Dis. 2009;64:247-55.

14. Postic D, Riquelme-Sertour N, Merien F, Perolat P, Baranton G. Interest of partial 16S rDNA gene sequences to resolve heterogeneities between Leptospira collections: application to L. meyeri. Res Microbiol. 2000;151:333-41.
15. Gökmen TG, Soyal A, Kalayci Y, Önlen C, Köksal F. Comparison of 16S rRNA-PCR-RFLP, LipL32-PCR and OmpL1-PCR methods in the diagnosis of leptospirosis. Rev Inst Med Trop Sao Paulo. 2016;58:64.

16. Bedir O, Kilic A, Atabek E, Kuskucu AM, Turhan V, Basustaoglu C. Simultaneous detection and differentiation of pathogenic and nonpathogenic Leptospira spp. by Multiplex real-Time PCR (TaqMan) assay. Pol J Microbiol. 2010;59:167-73.

17. Salaün L, Mérien F, Gurianova S, Baranton G, Picardeau M. Application of multilocus variable-number tandem-repeat analysis for molecular typing of the agent of leptospirosis. $\mathrm{J}$ Clin Microbiol. 2006;44:3954-62.

18. Hunter SB, Vauterin P, Lambert-Fair MA, Van Duyne MS, Kubota $\mathrm{K}$, Graves L, et al. Establishment of a universal size standard strain for use with the PulseNet standardized Pulsed-Field Gel Electrophoresis protocols: converting the national databases to the new size standard. J Clin Microbiol. 2005;43:1045-50.

19. Boonsilp S, Thaipadungpanit J, Amornchai P, Wuthiekanun V, Bailey MS, Holden MT, et al. A single multilocus sequence typing (MLST) scheme for seven pathogenic Leptospira species. PLoS Negl Trop Dis. 2013;7:e1954.

20. Katoh K, Standley DM. MAFFT Multiple Sequence Alignment software version 7: improvements in performance and usability. Mol Biol Evol. 2013;30:772-80.

21. Hem S, Ly S, Votsi I, Vogt F, Asgari N, Buchy P, et al. Estimating the burden of leptospirosis among febrile subjects aged below 20 Years in Kampong Cham communities, Cambodia, 20072009. PLoS One. 2016;11:e0151555.

22. Mgode GF, Machang'u RS, Mhamphi GG, Katakweba A, Mulungu LS, Durnez L, et al. Leptospira serovars for diagnosis of Leptospirosis in humans and animals in Africa: common Leptospira isolates and reservoir hosts. PLoS Negl Trop Dis. 2015;9:e004251.

23. Matthias MA, Ricaldi JN, Cespedes M, Diaz MM, Galloway RL, Saito M, et al. Human Leptospirosis caused by a new, antigenically unique Leptospira associated with a Rattus species reservoir in the peruvian Amazon. PLoS Negl Trop Dis. 2008;2:e213.

24. Wuthiekanun V, Chierakul W, Limmathurotsakul D, Smythe LD, Symonds ML, Dohnt MF, et al. Optimization of culture of Leptospira from humans with Leptospirosis. J Clin Microbiol. 2007;45:1363-5.

25. Scialfa E, Bolpe J, Bardón JC, Ridao G, Gentile J, Gallicchio O. Isolation of Leptospira interrogans from suburban rats in Tandil, Buenos Aires, Argentina. Rev Argent Microbiol. 2010;42:126-8.

26. Victoria B, Ahmed A, Zuerner RL, Ahmed N, Bulach DM, Quinteiro J, et al. Conservation of the S10-spc-alpha locus within otherwise highly plastic genomes provides phylogenetic insight into the genus Leptospira. PLoS One. 2008;3:e2752. 
27. Chiriboga J, Barragan V, Arroyo G, Sosa A, Birdsell DN, España $\mathrm{K}$, et al. High prevalence of intermediate Leptospira spp. DNA in febrile humans from urban and rural Ecuador. Emerg Infect Dis. 2015;21:2141-7.

28. Pereira MM, Matsuo MG, Bauab AR, Vasconcelos SA, Moraes ZM, Baranton G, et al. A clonal subpopulation of Leptospira interrogans sensu stricto is the major cause of Leptospirosis outbreaks in Brazil. J Clin Microbiol. 2000;38:450-2.

29. Silva EF, Cerqueira GM, Seyffert N, Seixas FK, Hartwig DD, Athanazio DA, et al. Leptospira noguchii and human and animal Leptospirosis, southern Brazil. Emerg Infect Dis. 2009;15:621-3.

30. da Cunha CE, Felix SR, Neto AC, Campello-Felix A, Kremer FS, Monte LG, et al. Infection with Leptospira kirschneri serovar Mozdok: first report from the southern hemisphere. Am J Trop Med Hyg. 2016;94:519-21.

31. Peláez Sanchez RG, Lopez JA, Pereira MM, Naranjo MA, Agudelo-Flórez P. Genetic diversity of Leptospira in northwestern Colombia: first report of Leptospira santarosai as a recognised leptospirosis agent. Mem Inst Oswaldo Cruz. 2016;111:737-44.
32. Varni V, Koval A, Nagel A, Ruybal P, Caimi K, Amadio AF. First genome sequence of Leptospira interrogans serovar Pomona, isolated from a bovine abortion. Genome Announc. 2016;4:e00345-16.

33. Chiani Y, Jacob P, Varni V, Landolt N, Schmeling MF, Pujato N, et al. Isolation and clinical sample typing of human leptospirosis cases in Argentina. Infect Genet Evol. 2016;37:245-51.

34. Trueba G, Zapata S, Madrid K, Cullen P, Haake D. Cell aggregation: a mechanism of pathogenic Leptospira to survive in fresh water. Int Microbiol. 2004;7:35-40.

35. Mason MR, Encina C, Sreevatsan S, Muñoz-Zanzi C. Distribution and diversity of pathogenic Leptospira species in peri-domestic surface waters from south central Chile. PLoS Negl Trop Dis. 2016;10:e004895.

36. Benacer D, Woh PY, Mohd Zain SN, Amran F, Thong KL. Pathogenic and saprophytic Leptospira species in water and soils from selected urban sites in peninsular Malaysia. Microbes Environ. 2013;28:135-40. 